\title{
UNITED STATES GEOLOGICAL SURVEY
}

W. E. WRATHER, DIRECTOR

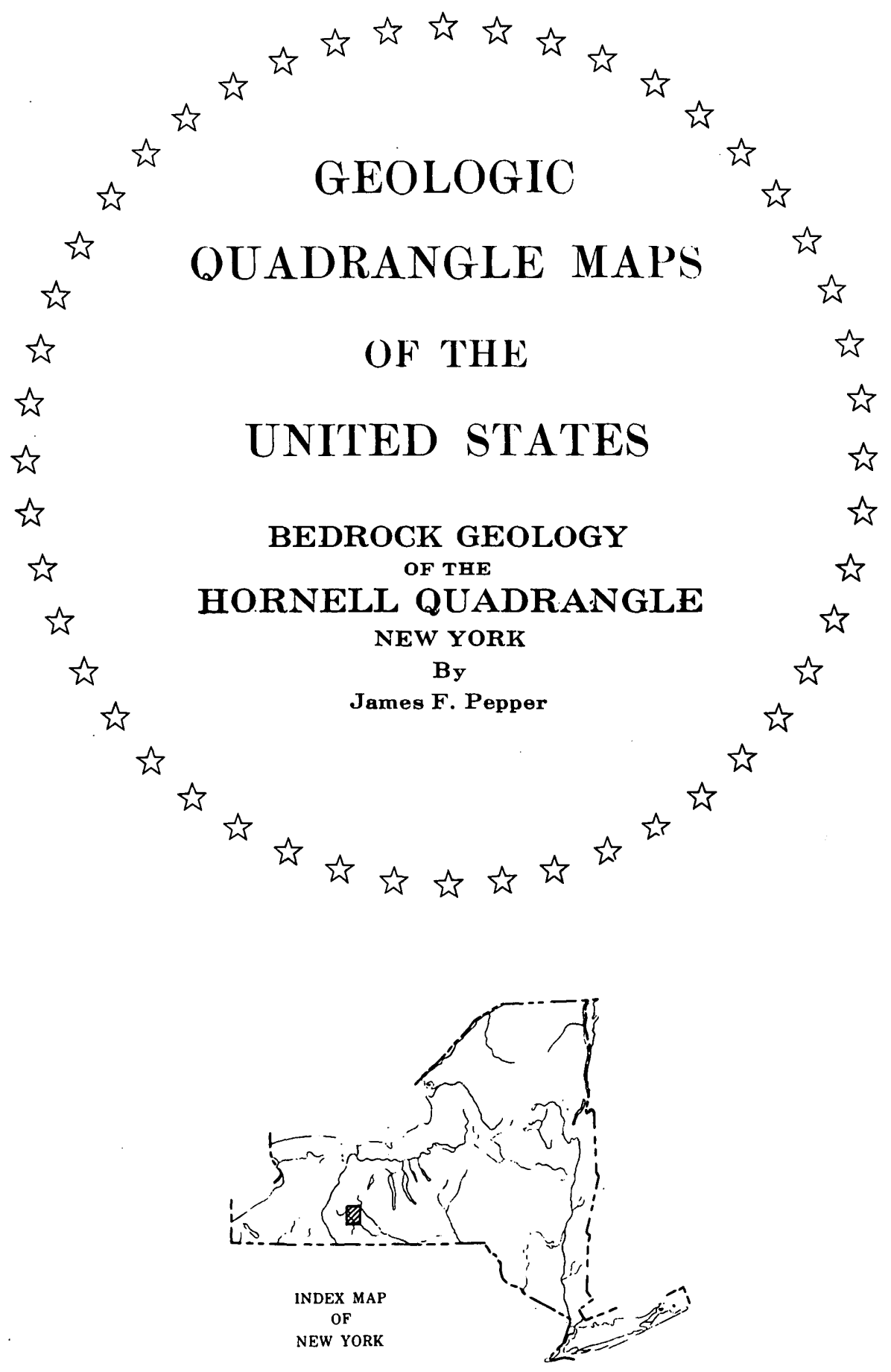

PUBLISHED BY THE U. S. GEOLOGICAL SURVEY WASHINGTON. D.C. 
The present series of Geologic Quadrangle Maps of the United States continues the project of geologically mapping the entire country, begun with the folios of the Geologic Atlas of the United States, which were published from 1894 to 1945 . The new series consists of geologic maps, supplemented where possible by structure sections, columnar sections, and other graphic means of presenting geologic data and accompanied by the minimum of explanatory text required to make the maps useful for general scientific and economic purposes. Full description of the areas shown on these maps and interpretation of the geologic history are reserved for publication in other channels, such as the Bulletins and Professional Papers of the Geological Survey.

Where additional types of geologic maps are required, separate maps of the same areas, covering bedrock, surficial, engineering, and other phases of geology, may be published in the geologic quadrangle map series. Each edition is issued in two forms-flat for filing in large map cases and folded for convenience in filing and for use in the field.

These maps may be obtained, flat or folded, from the U. S. Geological Survey, Washington 25, D. C., at the prices listed below. Prepayment is required and may be made by postal or express money order payable to the U. S. Geological Survey, or in cash-the exact amount-at sender's risk. Postage stamps are not accepted in payment for publications.

PUBLISHED MAPS IN THE

GEOLOGIC QUADRANGLE MAP SERIES

GQ 1 Bedrock geology of the Pawtucket quadrangle, Rhode Island-Massachusetts, by Alonzo W. Quinn, R. G. Ray, and W.L. Seymour, 1949 ............ \$0.60

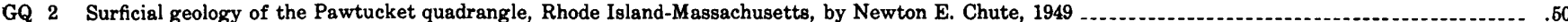

GQ 3 Bedrock geology of the Mount Grace quadrangle, Massachusetts, by Jarvis B. Hadley, 1949

GQ 4 Surficial geology of the Mount Grace quadrangle, Massachusetts, by Jarvis B. Hadley, 1949 .

GQ 5 Bedrock geology of the Brockton quadrangle, Massachusetts, by Newton E. Chute, 1950

GQ 6 Surficial geology of the Brockton quadrangle, Massachusetts, by Newton E. Chute, 1950

GQ 7 Geology of the Mount Tobin quadrangle, Nevada, by S. W. Muller, H. G. Ferguson, and Ralph J. Roberts, $1951 \ldots \ldots$

GQ 8 Bedrock geology of the Mount Toby quadrangle, Massachusetts, by Max E. Willard, 1951

GQ 9 Surficial geology of the Mount Toby quadrangle, Massachusetts, by Richard H. Jahns, 1951

GQ 10 Geology of the Antler Peak quadrangle, Nevada, by Ralph J. Roberts, 1951

GQ 11 Geology of the Winnemucca quadrangle, Nevada, by H. G. Ferguson, S. W. Muller, and Ralph J. Roberts, 1951 .

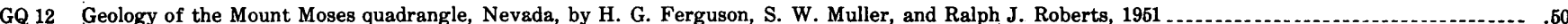

GQ 13 Bedrock geology of the North Scituate quadrangle, Rhode Island, by Alonzo W. Quinn, 1951

GQ 14 Geology of the Dannemora quadrangle, New York, by A. Williams Postel, 1951

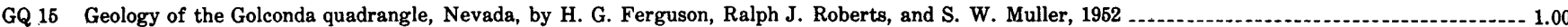

GQ 16 Bedrock geology of the Georgiaville quadrangle, Rhode Island, by Gerald M. Richmond, 1952 ,

GQ 17 Bedrock geology of the East Greenwich quadrangle, Rhode Island, by Alonzo W. Quinn, 1952 .

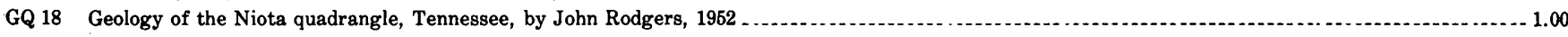

GQ 19 Geology of the Athens quadrangle, Tennessee, by John Rodgers, 1952

GQ 20 Bedrock geology of the Greenfield quadrangle, Massachusetts, by Max E. Willard, 1952

GQ 21 Surficial geology of the Ayer quadrangle, Massachusetts, by Richard H. Jahns, $1963 \ldots \ldots \ldots$

GQ 22 Surficial geology of the Georgiaville quadrangle, Rhode Island, by Gerald M. Richmond, 1953

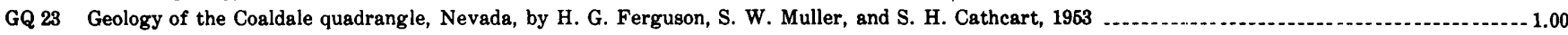

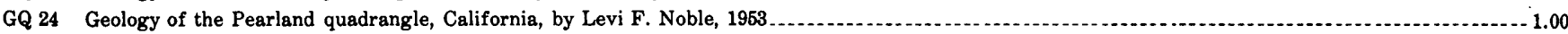

GQ 25 Geology of the Galice quadrangle, Oregon, by F. G. Wells and G. W. Walker, 1953

GQ 26 Geology of the Bowbells quadrangle, North Dakota, by Richard W. Lemke and Clifford A. Kay, 1953 $\ldots \ldots \ldots$

GQ 27 Bedrock geology of the Ahmeek quadrangle, Michigan, by Walter S. White, Henry R. Cornwall, and Roger W. SwanBon, 1953........................ 1.00

GQ 28 Geology of the Carlisle quadrangle, Pennsylvania, by George W. Stose, 1953

GQ 29 Geology of the Eagleton quadrangle, Montana, by Robert M. Lindvall, 1953

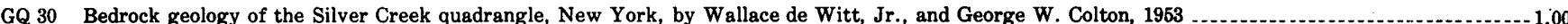

GQ 31 Geology of the Velva quadrangle, North Dakota, by Richard W. Lemke, $1953 \ldots \ldots \ldots$

GQ 32 Geology of the Pierre quadrangle, South Dakota, by Dwight R. Crandell, 1954

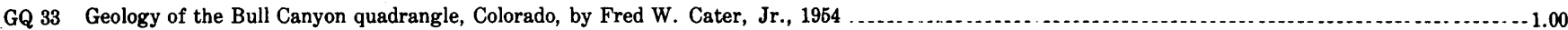

GQ 34 Bedrock geology of the Phoenix quadrangle, Michigan, by Henry R. Cornwall, $1964 \ldots \ldots$

GQ 35 Bedrock geology of the Bruneau Creek quadrangle, Michigan, by James C. Wright and Henry R. Cornwall, 1954 .............................

GQ 36 Bedrock geology of the Eagle Harbor quadrangle, Michigan, by Henry R. Cornwall and James C. Wright, 1954 $\ldots \ldots \ldots$

GQ 37 Bedrock geology of the Hornell quadrangle, New York, by James F. Pepper, 1954 